\title{
Feeding ecology of larvae of southern bluefin, albacore and skipjack tunas (Pisces: Scombridae) in the eastern Indian Ocean
}

\author{
Jock W. Young, Tim L. O. Davis \\ CSIRO Division of Fisheries, GPO Box 1538, Hobart, Tasmania 7001, Australia
}

\begin{abstract}
Copepod nauplii, calanoids, cyclopoids and cladocerans (all Crustacea) were the main prey of the larvae of southern bluefin Thunnus maccoyii and albacore tuna $T$. alalunga in the eastern Indian Ocean, although the importance of each prey type differed between the 2 species. Cannibalism was found in post-flexion T. maccoyii. Skipjack tuna Katsuwonus pelamis larvae fed mainly on appendicularians and fish larvae. T. maccoyii selected for copepod nauplii and corycaeids and against calanoids. $T$ alalunga selected for corycaeids and against calanoids. $K$. pelamis selected for appendicularians. The 2 Thunnus species fed only by day, with peaks in feeding in the early morning and late afternoon. The gut evacuation time of $T$ alalunga was estimated at ca $4 \mathrm{~h}$. Indexes of feeding success in $T$ maccoyij were positively correlated with zooplankton biomass, which suggests food was limited. Estimates of the daily ration and abundance of larval tuna and the abundance of microzooplankton in the study area indicate that larval $T$ maccovii can affect the abundance of their microzooplankton prey.
\end{abstract}

\section{INTRODUCTION}

The ability of a fish to find sufficient food in its early lifehistory stages can be a major determinant of its recruitment success (Hjort 1914, May 1974, Lasker 1975). Therefore, knowledge of the feeding ecology of fish larvae is essential for understanding their early life-history and recruitment variability. Much of the knowledge of larval feeding has, to date, been gained from larvae of temperate and subtropical fish species (Hunter 1981); information on tropical larvae is scant (Jenkins et al. 1984, Nishikawa 1975, Uotani et al. 1981, Schmitt 1986).

The diets of larval Thunnus maccoyii and other tuna species from the eastern Indian Ocean have been described by Uotani et al. (1981). However, these workers sampled a large area (hundreds of kilometres) over long time periods (weeks to months), whereas smaller spatial and temporal scales are more relevant to the life-history of the larvae. For example, there is no information on diel cycles of feeding in these larvae. Nevertheless, they established that the diet of $T$. maccoyii and related species (including $T$. alalunga) consisted mainly of copepod nauplii, cyclopoid copepods (Corycaeus spp.), calanoids (Clausocalanus spp.) and cladocerans (Evadne spp.), whereas larvae of other tuna species (Auxis spp. and Katsuwonus pelamis) fed primarily on appendicularians and cladocerans.
Recent work (e.g Cushing 1983, Peterson \& Ausubel 1984, Jenkins 1987) has indicated that fish larvae are generally too few to affect the density of their prey populations. However, the surface waters of the eastern Indian Ocean are low in nutrients (Rochford 1962), which could mean there are fewer prey suitable for larval fishes. Therefore, as larval tuna are at times very abundant in these waters (Davis \& Clementson 1989), they may be able to affect the abundance of their prey. If they do, not only intraspecific, or density-dependent, competition is likely, but also interspecific competition between co-occurring species. As part of a larger study of factors affecting the distribution of tuna larvae in the eastern Indian Ocean (Davis \& Clementson 1989), larvae of Thunnus maccoyii, $T$. alalunga and Katsuwonus pelamis were collected for dietary analysis. In this paper we examine differences in their diets and feeding habits and examine their potential to reduce prey levels in the area.

\section{MATERIALS AND METHODS}

Collection of larvae and microzooplankton. Tuna larvae were collected from plankton tows made in an area of ca $300 \mathrm{~km}^{2}$ centred on $16^{\circ} 30^{\prime} \mathrm{S}, 115^{\circ} 50^{\prime} \mathrm{E}$ (Fig. 1) between 29 and 31 January 1987, during a study of 


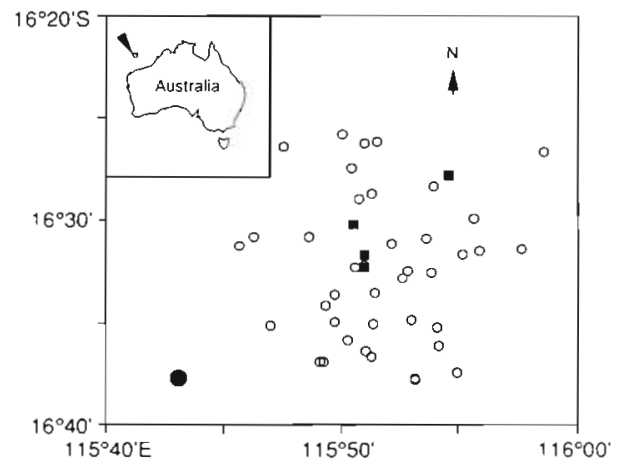

Fig. 1. Location of sampling stations in the eastern Indian Ocean. (o) Ring-net samples ( $)$; drop-net samples; ( $\bullet$ ) site of gut evacuation study

the distribution and abundance of larvae of Thunnus maccoyii in the eastern Indian Ocean (Davis \& Clementson 1989). The sampling procedure is described in more detail in Davis et al. (1990). Concurrent surface and oblique tows (to the bottom of the mixed layer) were made by day and by night at positions randomly fixed within a $20 \mathrm{~km}$ radius of a drogued buoy. Surface and oblique tows were made with identical $70 \mathrm{~cm}$ ring nets, with $500 \mu \mathrm{m}$ mesh aperture netting. Each net was equivalent to one side of a $70 \mathrm{~cm}$ bongo net. All nets were fitted with a General Oceanics flowmeter. The samples were stored in $95 \%$ ethanol. The stomach contents of larvae of 3 species of tuna (Thunnus maccoyii, $T$. alalunga and Katsuwonus pelamis) were examined. Larvae were identified on pigment pattern using the criteria of Nishikawa (1985) and Nishikawa \& Rimmer (1987). As difficulties were encountered in separating some larvae of $T$. alalunga from the closely related $T$. albacares (see Richards et al. in press) we only examined larvae of sizes where mis-identification was unlikely.

Microzooplankton were collected in the study area (Fig. 1) with a $100 \mu \mathrm{m}$ mesh aperture drop net (Heron 1982). Each 'drop' consisted of a cast from the surface through the mixed layer to a depth of $60 \mathrm{~m}$. The samples were fixed in 5\% formaldehyde. An experiment to measure gut evacuation was set up on a later cruise to the study area in November 1987 (Fig. 1). On this occasion, oblique tows to a depth of about $20 \mathrm{~m}$, using a $70 \mathrm{~cm}$ bongo net with $500 \mu \mathrm{m}$ mesh aperture netting, were made past a drogued buoy at half-hourly intervals from 15:00 to 22:00 h $(n=14)$ on 22 November. Each tow lasted around $15 \mathrm{~min}$. A $20 \mathrm{~cm}$ diameter 'pup' net (mesh aperture $50 \mu \mathrm{m}$ ) was hung within one side of the bongo net to collect microzooplankton.

Laboratory analysis. Larvae for analysis were measured in glycerine under a stereo-microscope. Standard length was measured from the tip of snout to the end of notochord in preflexion larvae, or to the hypural crease in post-flexion larvae (standard length [SL] \pm 0.005 $\mathrm{mm}$ ). Mouth width was measured, on the ventral surface, as the width between the posterior edge of the maxillae (mouth width $[\mathrm{mw}] \pm 0.005 \mathrm{~mm}$ ). However, mouth width measurements tended to vary with the state of preservation of the larva (see Table 2), therefore a further measure of mouth size, the distance along the maxillae (lower jaw length [ljl] $\pm 0.005 \mathrm{~mm}$ ), was taken. The stomach contents were teased from the stomach with $0.25 \mathrm{~mm}$ tungsten needles electrolytically sharpened for the purpose. The contents were identified to the lowest possible taxa, measured along the shortest and longest axes, and counted. Chlorozol Black E was added to the glycerine to aid identification of Crustacea. Stomach fullness (s) was estimated on a scale of 1 to 5 ( $1=$ empty $^{2}<$ half-full $_{i} \approx$ half-full $; 4$ $>$ half-full $5=$ full). The stage of digestion (d) was estimated on a scale of 1 to $3(1=$ digested; $2=$ partially digested; $3=$ contents intact).

The total zooplankton biomass in each oblique tow from the January 1987 cruise was estimated from settled and displacement volumes (see Omori \& Ikeda 1984, p. 87). The volume for each sample was standardised by dividing the volume of zooplankton by the volume of water filtered. Zooplankton biomass was expressed as $\mathrm{ml} 100 \mathrm{~m}^{-3}$. The numbers and dry weight of microzooplankton were assessed from the drop net samples in January 1987 and from the pup nets in November 1987. Each sample was divided in a Folsom splitter, with one half retained for estimation of biomass and the other for estimation of prey numbers. For estimation of biomass, each sample was filtered through a series of sieves of mesh aperture sizes 1000 $\mu \mathrm{m}, 333 \mu \mathrm{m}$ and $100 \mu \mathrm{m}$. Each fraction was retained on pre-weighed filter paper, dried at $70^{\circ} \mathrm{C}$ for $24 \mathrm{~h}$, and weighed to an accuracy of $\pm 10 \mu \mathrm{g}$, following Frank (1988). For estimation of prey numbers, samples were initially filtered through a $1 \mathrm{~mm}$ screen to exclude zooplankters of a larger size than that eaten by the tunas (Young unpubl.). Five aliquots, each representing $1 / 40$ of the total sample, were taken with a Stempel pipette (volume $=5 \mathrm{ml}$ ) from the resuspended samples, and from which microzooplankton were sorted and counted to the major prey groupings. Only taxa eaten by larval tuna were counted (Young unpubl.).

Data analysis. The stomach contents of larvae from different locations in the study area were examined (Fig. 1). For the purpose of this study we assumed that the feeding characteristics of larvae from the different locations were directly comparable. The relative importance of prey items in the diet of each species of larval tuna was determined from the product of percent frequency of occurrence and percent number (Govoni et al. 1983).

Dietary overlaps were measured with the Schoener Index (Schoener 1970) which, in this case, compared 
the relative proportions of prey numbers eaten by the 3 species of tuna larvae. This index ranges from 0 (no overlap) to 1 (complete overlap). Prey numbers were used, as the prey species differed little in size (Wallace 1981).

Diet breadth was analysed using Levins' (1968) formula, $B=\left(\Sigma p_{1}^{2}\right)^{-1}$, where $p_{1}=$ proportion of a prey taxon in the diet. Values were standardised to fractions by Hespenheide's (1975) Method. Comparison was also made of prey sizes, using the logarithmic transformation of Pearre (1986) to assess differences between species in the width of their prey. Pearre's C Index (Eqs. 1 and 3, p. 914-915, Pearre 1982) was chosen to assess prey selection as it conforms to most of the requirements of the 'ideal' selectivity index (Lechowicz 1982) and statistically testable. To counter the limitations imposed on the prey selection study by using different nets to capture predator and prey (Merrett \& Roe 1974, Angel 1977), selectivity values were also calculated for larvae of Thunnus alalunga caught on the November cruise, when a pup net, hung inside the bongo net, was used to sample prey.

In the 2 Thunnus species, indicators of feeding intensity (i.e. stomach fullness, state of digestion and number of prey) were examined with respect to time of day, using nonparametric ANOVA (Kruskal-Wallis Test [KW], Zar 1984), as the number of empty stomachs (zero values) in the data set was greater than $20 \%$.

Regression analysis was used to predict the gut evacuation rate and time (duration) in the larvae. A regression was fitted to prey numbers versus time, from the time of maximum feeding (just prior to dusk) to the time when all stomachs were empty. The daily ration of the Thunnus species was estimated with the formula (Eq. 9) of Elliot \& Persson (1978). This method combines the sum of food present at intervals during the day with the rate of digestion to estimate the total amount of food eaten per day. The mean number of prey per larvae was calculated for the Thunnus species for each $2 \mathrm{~h}$ interval from 08:00 h until stomachs were empty (22:00 h). Correlation coefficients were calculated for the relationship between zooplankton volume and indices of feeding.

\section{RESULTS}

\section{Feeding incidence}

The gut contents of 583 Thunnus maccoyï caught by day and by night were examined. The larvae ranged in size from 2.69 to $9.84 \mathrm{~mm} \mathrm{SL}$, although most were between 4 and $5 \mathrm{~mm} \mathrm{SL}$ (Fig. 2). In all, 38.8\% of the guts contained food. However, of the larvae caught in daylight $(06: 00$ to $18: 00$ h) $52.7 \%$ had food in their
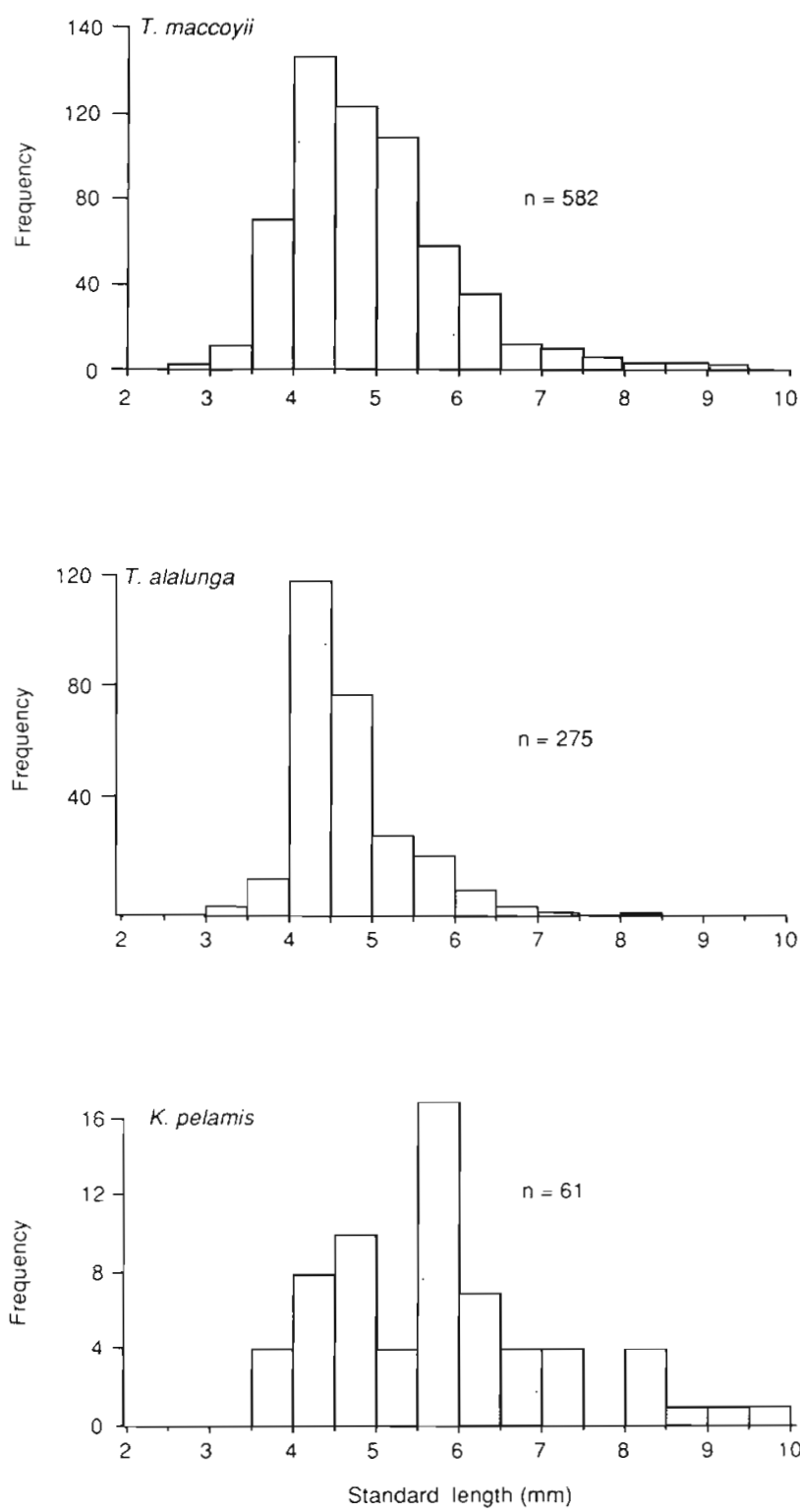

Fig. 2. Thunnus maccoyii, T. alalunga and Katsuwonus pelamis. Length-frequency distributions of larvae examined for gut contents

stomachs. During daytime, the percentage of stomachs containing food (feeding incidence) was positively correlated with size of larvae in T. maccoyii $\left(\mathrm{r}^{2}=0.91, \mathrm{p}<\right.$ 0.001). In $T$. alalunga, of 275 larvae examined (Fig. 2), $44.7 \%$ contained food (55\% in daytime samples). Feeding incidence was also positively correlated with size of larvae in daytime samples $\left(\mathrm{r}^{2}=0.71, \mathrm{p}<0.05\right)$. Fewer larvae of Katsuwonus pelamis were available for examination (Fig. 2, $n=61$ ). Of these, $30.8 \%$ contained food ( $41.5 \%$ contained food in daytime samples). During the gut evacuation experiment a similar number of $K$. pelamis were taken $(\mathrm{n}=54)$, but only 4 larvae contained food $(7.4 \%)$. 


\section{Overall diet and dietary overlap}

In Thunnus maccoyii the main prey items, in order of importance, were calanoid copepods (mainly Clausocalanus furcatus and Paracalanus spp., although the condition of many calanoids made identification difficult), cyclopoid copepods (Corycaeus spp., Farranula gibbula), copepod nauplii and the cladoceran Evadne tergesina (Table 1). Fish larvae were important in the diets of the few post-flexion larvae examined. Although the overall diet of $T$. alalunga was similar to that of $T$. maccoyii (Schoener's Index, $a_{1}=0.57$ ), cyclopoids (Corycaeus spp. and Farranula gibbula), followed by copepod nauplii, were the main prey items. Calanoids and cladocerans were taken less frequently. The relative proportions of prey eaten by the 2 Thunnus species did not differ significantly with size $(a=0.53$ for larvae $\leq 4.5 \mathrm{~mm} ; \mathrm{a}=0.58$ for larvae $>4.5 \mathrm{~mm}$ ). Katsuwonus pelamis fed mainly on appendicularians and fish larvae. Accordingly, its diet overlapped very little with those of $T$. maccoyii and $T$. alalunga $(\mathrm{a}=0.20$ and 0.15 respectively).

\section{Diet breadth}

In Thunnus maccoyii diet breadth was least in fish less than $4.75 \mathrm{~mm}$ in length (Fig. 3a). Copepod nauplii were the main food of these larvae (Table 1). Diet breadth increased in larger-sized larvae with the introduction of other prey taxa into their diet. Conversely, in $T$. alalunga diet breadth was greatest in larvae less than $5.5 \mathrm{~mm}$ (Fig. 3a), due to the presence of nauplii, copepod eggs and corycaeids (mainly Farranula gibbula). Diet breadth decreased with size in $T$. alalunga, because the diet was increasingly dominated by cory-

Table 1. Summary of prey items of Thunnus maccoyii (size range SL $=2.69$ to $9.84 \mathrm{~mm}$, mean $=4.82 \pm 0.90[S D$ ] $\mathrm{mm}$ ), $T$ alalunga $(S L=3.77$ to $6.12 \mathrm{~mm}$, mean $=4.68 \pm 0.55[\mathrm{SD}] \mathrm{mm}$ ) and Katsuwonus pelamis $(\mathrm{SL}=3.79$ to $9.95 \mathrm{~mm}$, mean $=5.76 \pm 1.37[\mathrm{SD}]$ $\mathrm{mm}$ ) in January 1987 The product (F.N) of frequency of occurrence $(F)$ and percentage number $(\mathrm{N})$ of each prey type is a measure of the importance of each prey type

\begin{tabular}{|c|c|c|c|c|c|c|c|c|c|}
\hline \multirow[t]{2}{*}{ Prey taxon } & \multicolumn{3}{|c|}{$T$ maccoyii $(\mathrm{n}=583)$} & \multicolumn{3}{|c|}{$T$ alalunga $(n=275)$} & \multicolumn{3}{|c|}{ K. pelamis $(\mathrm{n}=65)$} \\
\hline & $F$ & N & F.N & $F$ & $N$ & $F \cdot N$ & F & $N$ & FN \\
\hline \multicolumn{10}{|l|}{ Dinoflagellata } \\
\hline Ceratium spp. & 0.19 & 0.32 & 0.06 & - & - & - & - & - & - \\
\hline Foraminifera & 0.19 & 0.32 & 0.06 & - & - & - & - & - & - \\
\hline Chaetognatha & 0.19 & 0.32 & 0.06 & - & - & - & - & - & - \\
\hline \multicolumn{10}{|l|}{ Crustacea } \\
\hline \multicolumn{10}{|l|}{ Cladocera } \\
\hline Evadne tergestina & 2.33 & 4.46 & 10.39 & 2.63 & 3.85 & 10.13 & - & - & - \\
\hline \multicolumn{10}{|l|}{ Copepoda } \\
\hline \multicolumn{10}{|l|}{ Cyclopoida } \\
\hline Corycaeus spp. & 10.27 & 19.43 & 199.55 & 18.42 & 32.05 & 590.36 & - & - & - \\
\hline Corycaeus spinosus & 0.58 & 0.96 & 0.56 & - & - & - & - & - & - \\
\hline Farranula gibbula & 3.68 & 7.32 & 26.94 & 16.67 & 25.64 & 427.42 & - & - & - \\
\hline Oithona spp. & 1.16 & 1.91 & 2.22 & - & - & - & - & - & - \\
\hline Saphirina spp. & 0.19 & 0.32 & 0.06 & - & - & - & - & - & - \\
\hline \multicolumn{10}{|l|}{ Calanoida } \\
\hline Calanidae & 1.16 & 1.91 & 2.22 & - & - & - & - & - & - \\
\hline Acrocalanus spp. & 0.38 & 0.64 & 1.52 & - & - & - & - & - & - \\
\hline Calanus spp. & 0.38 & 0.64 & 1.52 & - & - & - & - & - & - \\
\hline Clausocalanus furcatus & 3.87 & 4.26 & 16.49 & 0.88 & 1.28 & 1.13 & - & - & - \\
\hline Cosmocalanus darwinii & 0.58 & 0.96 & 0.56 & 0.88 & 1.28 & 1.13 & - & - & - \\
\hline Labidocera spp. & 0.19 & 0.32 & 0.06 & - & - & - & - & - & - \\
\hline Neocalanus robustior & 0.19 & 0.64 & 0.12 & - & - & - & - & - & - \\
\hline Paracalanus spp. & 0.58 & 0.96 & 0.56 & - & - & - & - & - & - \\
\hline Scolecithrix spp. & 0.19 & 0.32 & 0.06 & - & - & - & - & - & - \\
\hline Unid. calanoids & 11.63 & 21.97 & 255.51 & 4.39 & 6.41 & 28.14 & 4.88 & 11.11 & 54.22 \\
\hline eggs & 1.94 & 4.18 & 8.11 & 0.88 & 1.28 & 1.13 & - & - & $\cdots$ \\
\hline nauplii & 14.73 & 24.20 & 356.47 & 17.54 & 28.21 & 494.80 & 2.44 & 5.56 & 13.57 \\
\hline Appendicularia & 0.19 & 0.64 & 0.12 & - & - & - & 21.95 & 50.00 & 1097.50 \\
\hline Fish larvae & 1.94 & 2.06 & 4.00 & - & - & - & 12.20 & 33.33 & 406.63 \\
\hline Thunnus maccoyii & 0.58 & 0.96 & 0.56 & - & - & - & - & - & - \\
\hline $\begin{array}{l}\text { Mean number of prey per } \\
\text { stomach }( \pm \mathrm{SE})\end{array}$ & \multicolumn{3}{|c|}{$0.85( \pm 0.05)$} & \multicolumn{3}{|c|}{$1.14( \pm 0.17)$} & \multicolumn{3}{|c|}{$0.44(-0.09)$} \\
\hline Range & \multicolumn{3}{|c|}{$0-6$} & \multicolumn{3}{|c|}{$0-8$} & \multicolumn{3}{|c|}{$0-2$} \\
\hline
\end{tabular}


caeids. Diet breadth was low in Katsuwonus pelamis (B $=0.083$ - all sizes combined) due to the absence of crustacean prey taxa

The logarithmic mean widths of prey eaten by Thunnus maccoyii and $T$. alalunga were very similar (Fig. $3 \mathrm{~b})$. However, the greater breadth in the diet of larger I maccoyil is reflected in the greater standard deviations of prey widths about the mean than in similarsized $T$. alalunga
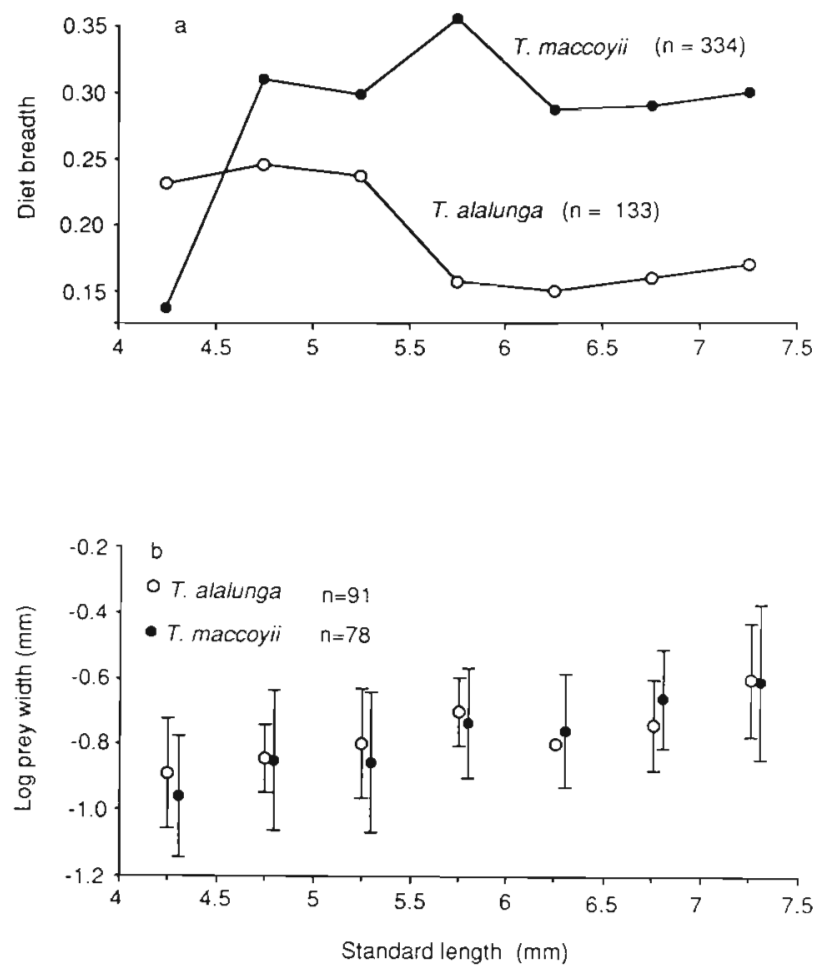

Fig. 3 (a).Thunnus maccoyii ( $\bullet$ ) and $T$. alalunga (0). Diet breadths in relation to fish size using Levin's (1968) formula (b) Mean and standard deviation of logarithmically transformed prey widths in relation to fish size

\section{Relationship between mouth size and fish length}

Mouth width was significantly correlated with standard length in all 3 species, although a closer relationship was found between lower jaw length and standard length (Table 2). Mouth width also correlated with lower jaw length. The slopes of the regression lines of lower jaw length versus standard length for the 3 species were significantly different from each other (ANCOVA, $p=0.034$ ), and so a statistical comparison of lower jaw length with respect to size could not be made. However, for larvae of the same length, lower jaw length was largest in Katsuwonus pelamis and smallest in Thunnus alalunga (Fig. 4).

\section{Changes in diet with size}

Mouth width was positively correlated $\left(\mathrm{r}^{2}=0.34\right.$, df $=180, \mathrm{p}<0.001)$ with both prey width $(\mathrm{Pw})$ and prey length $(\mathrm{Pl})\left(\mathrm{r}^{2}=0.70\right.$, $\left.\mathrm{df}=90, \mathrm{p}<0.001\right)$ in Thunnus maccoyii, which ate larger prey taxa with increasing size. Copepod nauplii (Pw, range $=0.04$ to $0.16 \mathrm{~mm}$, mean $=0.087 \mathrm{~mm} \pm 0.007$ (95\% CL]) were eaten

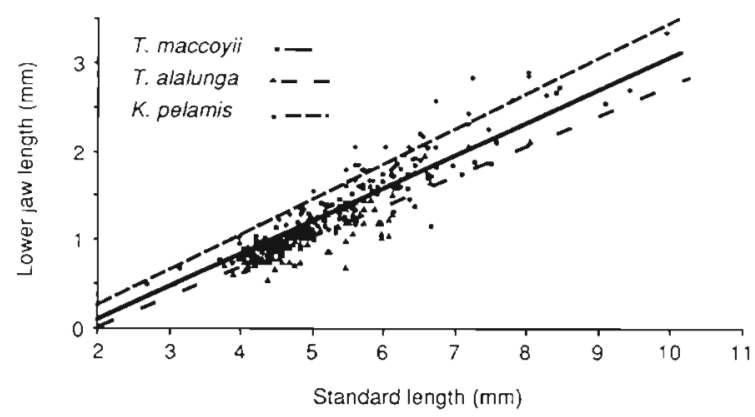

Fig. 4. Thunnus maccoyii, $T$ alalunga and Katsuwonus pelamis. Relationship between lower jaw length and larval standard length

Table 2. Thunnus maccoyii, $T$ alalunga and Katsuwonus pelamis. Regression equations and significance levels for relationships of mouth width (mw) and lower jaw length (ljl) with standard length (SL)

\begin{tabular}{|c|c|c|c|c|c|}
\hline Species & Equation & $r^{2}$ & df & $\mathrm{F}$ & $\mathrm{p}$ \\
\hline T. maccoyii & $\begin{array}{l}\mathrm{mw}=0.128 \mathrm{SL}-0.091 \\
\mathrm{ljl}=0.373 \mathrm{SL}-0.655 \\
\mathrm{mw}=0.327 \mathrm{ljl}+0.157\end{array}$ & $\begin{array}{l}0.68 \\
0.89 \\
0.70\end{array}$ & $\begin{array}{r}174 \\
146 \\
90\end{array}$ & $\begin{array}{r}361 \\
1182 \\
203\end{array}$ & $\begin{array}{l}<0.001 \\
<0.001 \\
<0.001\end{array}$ \\
\hline T. alalunga & $\begin{array}{l}\mathrm{mw}=0.096 \mathrm{SL}+0.011 \\
\mathrm{lj} \mathrm{l}=0.336 \mathrm{SL}-0.644 \\
\mathrm{mw}=0.226 \mathrm{lj} 1+0.256\end{array}$ & $\begin{array}{l}0.64 \\
0.81 \\
0.49\end{array}$ & $\begin{array}{l}127 \\
126 \\
126\end{array}$ & $\begin{array}{l}221 \\
534 \\
120\end{array}$ & $\begin{array}{l}<0.001 \\
<0.001 \\
<0.001\end{array}$ \\
\hline K. pelamis & $\begin{array}{l}\mathrm{mw}=0.117 \mathrm{SL}+0.356 \\
\mathrm{ljl}=0.397 \mathrm{SL}-0.529 \\
\mathrm{mw}=0.325 \mathrm{ljl}+0.453\end{array}$ & $\begin{array}{l}0.29 \\
0.89 \\
0.37\end{array}$ & $\begin{array}{l}24 \\
42 \\
24\end{array}$ & $\begin{array}{c}9.5 \\
321 \\
13.4\end{array}$ & $\begin{array}{l}=0.005 \\
<0.001 \\
=0.013\end{array}$ \\
\hline
\end{tabular}


mainly by larvae less than $5 \mathrm{~mm} \mathrm{SL}$. These were gradually replaced by cyclopoids ( $\mathrm{PW}_{\mathrm{w}}$, range $=0.06$ to 0.30 $\mathrm{mm}$, mean $=0.171 \mathrm{~mm} \pm 0.016[95 \% \mathrm{CL}])$ and finally by calanoids ( $\mathrm{Pw}$, range $=0.08$ to $0.32 \mathrm{~mm}$, mean $=$ $0.201 \pm 0.02$ [95\% CL]) and fish larvae in larvae greater than $7 \mathrm{~mm} \mathrm{SL}$ (Fig. 5). Pre-flexion larvae of $T$. maccoyii (SL $<4.0 \mathrm{~mm}$ ) were identified from the stomachs of 3 post-flexion $T$. maccoyii. In $T$. maccoyii the mean width of calanoid prey was significantly greater than cyclopoid prey (Student's t-test, $\mathrm{df}=45, \mathrm{t}=$ $2.21, p=0.0325)$. No difference, however, was found in the mean lengths of these prey.

Prey width was positively correlated with mouth width in Thunnus alalunga $\left(\mathrm{r}^{2}=0.26\right.$, $\mathrm{df}=95, \mathrm{p}<$ $0.001)$. Nauplii were mainly eaten by the smaller larvae. Cyclopoids (mainly corycaeids), which were of similar lengths, were eaten by all sizes of $T$. alalunga, but were more frequent in the diet of larger larvae, which also ate cladocerans (Evadne tergestina) (Fig. 5).

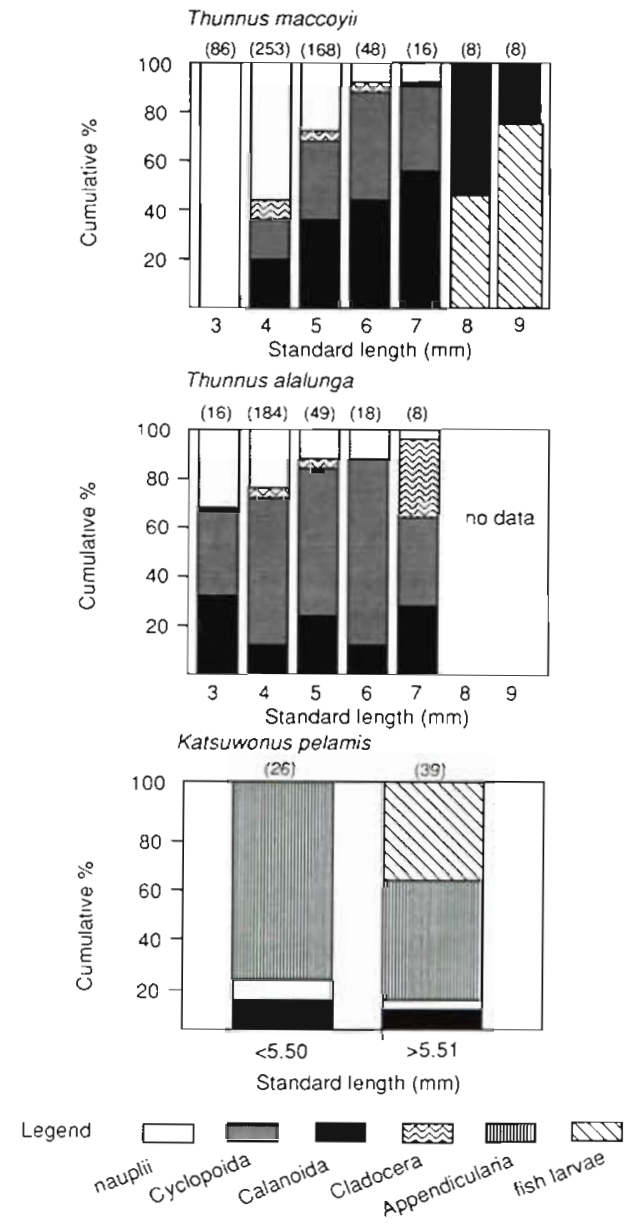

Fig. 5. Thunnus maccoyii, $T$ alalunga and Katsuwonus pelamis. Frequency of occurrence of major prey taxa in relation to size class. Prey taxa are listed in order of increasing size in legend. Numbers of larvae examined in each size class are given in brackets
Calanoids constituted a third or less of the diets of all sizes.

It was not possible to measure prey width in Katsuwonus pelamis, as the main dietary component of this species, Appendicularia, consists of gelatinous zooplankters that become distorted in the stomach. However, the presence of fish larvae in the gut contents of larger individuals indicated an ontogenetic shift in diet (Fig. 5).

\section{Numbers of prey}

In Thunnus maccoyii the number of prey items per stomach ranged from 0 to 6 but did not differ with increasing size (Fig. 6) which indicates selection for larger (wider) prey types rather than for increased numbers of the same prey. In $T$. alalunga the numbers of prey per stomach ranged from 0 to 34 . Numbers of prey eaten were positively correlated with standard length in $T$. alalunga $\left(\mathrm{r}^{2}=0.17, \mathrm{df}=146, \mathrm{p}<0.001\right)$ (Fig. 6), reflecting that, within the size range examined, $T$. alalunga selected for increasing numbers of the same prey (mainly corycaeids), rather than eating larger prey types. Stomach contents were not enumerated in larval Katsuwonus pelamis because of rapid digestion of appendicularians, their main prey.

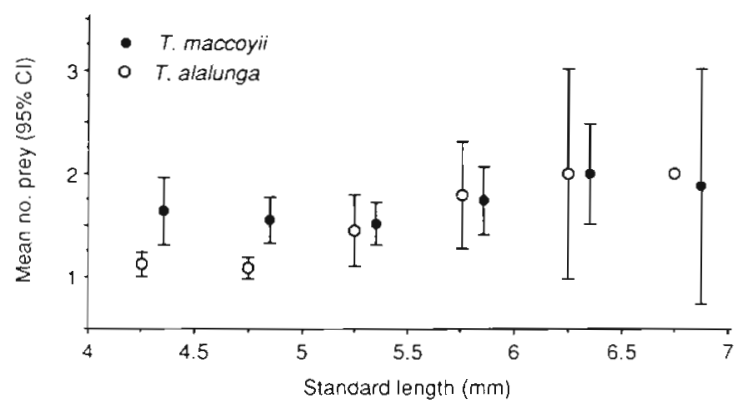

Fig. 6. Tunnus maccoyii $(\bullet$ ) and $T$ alalunga ( $)$. Relationship between mean number of prey and size of larvae

\section{Prey selection}

In the drop net samples, the total numbers of the microzooplankton taxa preyed on by the tunas ranged from 239 to $883 \mathrm{~m}^{-3}$ (Table 3). As both the relative proportions and the overall abundances of the microzooplankton sampled were patchy, selectivity indices were calculated separately for each sample. Consistent patterns of selection were apparent. Thunnus maccoyii of $\leq 5.0 \mathrm{~mm} \mathrm{SL}$ selected for copepod nauplii and corycaeid cyclopoids and selected against calanoids (Table 4). A similar pattern was observed in larvae 
Table 3. Overall abundance (numbers $\mathrm{m}^{-3}$ ) of microzooplankton taxa, and dry weight biomass (mg $\mathrm{m}^{-3}$ ) of microzooplankton retained in 1000, 333 and $100 \mu \mathrm{m}$ sieves, taken in drop net samples in January and pup net samples (Stn 190) in November 1987

\begin{tabular}{|c|c|c|c|c|c|}
\hline \multirow{2}{*}{$\begin{array}{l}\text { Abundance } \\
\text { Zooplankton taxa }\end{array}$} & \multicolumn{5}{|c|}{ Station number } \\
\hline & 194 & 255 & 297 & 308 & 190 \\
\hline Eggs & 97.2 & 18.2 & 26.9 & 146.6 & 31.2 \\
\hline Copepod nauplii & 114.6 & 9.9 & 14.4 & 151.0 & 67.4 \\
\hline Cyclopoida & 29.7 & 19.2 & 25.9 & 35.2 & 124.1 \\
\hline Calanoida & 299.2 & 157.1 & 185.3 & 492.5 & 250.6 \\
\hline Appendicularia & 46.1 & 34.6 & 52.5 & 57.3 & 45.3 \\
\hline Cladocera & - & - & - & - & 2.4 \\
\hline Total zooplankton & 586.8 & 239.0 & 305.0 & 882.6 & 521.0 \\
\hline \multicolumn{6}{|l|}{$\begin{array}{l}\text { Biomass } \\
\text { Size fractions }\end{array}$} \\
\hline$>1000 \mu \mathrm{m}$ & 2.15 & 1.16 & 2.95 & 1.86 & 0.79 \\
\hline$>333 \mu \mathrm{m}$ & 0.50 & 0.55 & 0.76 & 1.11 & 1.46 \\
\hline$>100 \mu \mathrm{m}$ & 0.10 & 0.02 & 0.07 & 0.50 & 0.07 \\
\hline
\end{tabular}

Table 4. Thunnus maccoyi, $T$ alalunga, Katsuwonus pelamis. Values of Pearre's C Index for larvae $\leq$ or $>5 \mathrm{~mm}$ SL feeding on copepod nauplii, corycaeids, calanoids and appendicularians. Positive $C$ values show selection for, and negative values show selection against, a particular prey taxon. Selectivity values for $T$. alalunga calculated from November samples (Stn 190) are given in brackets for all sizes combined. 'Selection for or against is significant at $p<0.05$; - : insufficient data for comparison

\begin{tabular}{|c|c|c|c|c|c|}
\hline Stn & $\leq 5.0 \mathrm{~mm}$ & $\begin{array}{l}T \text { maccoyii } \\
>5.0 \mathrm{~mm}\end{array}$ & $\leq 5.0 \mathrm{~mm}$ & $\begin{array}{c}T \text { alalunga } \\
>5.0 \mathrm{~mm}\end{array}$ & $\begin{array}{c}\text { K. pelamis } \\
\text { (all sizes) }\end{array}$ \\
\hline \multicolumn{6}{|c|}{ Copepod nauplii } \\
\hline 194 & $+0.20^{\circ}$ & -0.04 & +0.03 & +0.05 & - \\
\hline 255 & $+0.47^{\circ}$ & $+0.19^{\circ}$ & $+0.29^{\circ}$ & $+0.13^{\circ}$ & - \\
\hline 297 & $+0.46^{\circ}$ & $+0.18^{\circ}$ & $+0.27^{\circ}$ & $+0.11^{\bullet}$ & - \\
\hline 308 & $+0.21^{\circ}$ & -0.01 & +0.04 & +0.03 & - \\
\hline$(190)$ & - & - & \multicolumn{2}{|c|}{$(-0.09)$} & \\
\hline \multicolumn{6}{|c|}{ Corycaeids } \\
\hline 194 & $+0.26^{\circ}$ & $+0.38^{\circ}$ & $+0.57^{\circ}$ & $+0.61^{\circ}$ & - \\
\hline 255 & $+0.22^{\circ}$ & $+0.32^{\circ}$ & $+0.57^{\circ}$ & $+0.61^{\circ}$ & - \\
\hline 297 & $+0.21^{\circ}$ & $+0.32^{\circ}$ & $+0.50^{\circ}$ & $+0.59^{\circ}$ & - \\
\hline 308 & $+0.28^{\circ}$ & $+0.39^{\circ}$ & $+0.56^{\circ}$ & $+0.60^{\circ}$ & - \\
\hline$(190)$ & - & - & \multicolumn{2}{|c|}{$\left(+0.25^{\circ}\right)$} & \\
\hline \multicolumn{6}{|c|}{ Calanoids } \\
\hline 194 & $-0.18^{\circ}$ & -0.05 & $-0.27^{\circ}$ & $-0.20^{\circ}$ & - \\
\hline 255 & $-0.37^{\circ}$ & $-0.21^{*}$ & $-0.48^{\circ}$ & $-0.39^{\circ}$ & - \\
\hline 297 & $-0.31^{*}$ & $-0.15^{\circ}$ & $-0.41^{\circ}$ & $-0.32^{\bullet}$ & - \\
\hline 308 & $-0.19^{\circ}$ & $-0.08^{\circ}$ & $-0.25^{\circ}$ & $-0.19^{*}$ & - \\
\hline$(190)$ & - & - & \multicolumn{2}{|c|}{$(-0.41 \cdot)$} & \\
\hline \multicolumn{6}{|c|}{ Appendicularians } \\
\hline 194 & - & - & - & - & $+0.25^{\circ}$ \\
\hline 255 & - & - & - & - & $+0.22^{\circ}$ \\
\hline 297 & - & - & - & - & $+0.17^{\circ}$ \\
\hline 308 & - & - & - & - & $+0.22^{\circ}$ \\
\hline
\end{tabular}

$>5.0 \mathrm{~mm} \mathrm{SL}$, although their selection for copepod nauplii was relatively lower and for cyclopoids relatively higher. T. maccoyii of $>5.0 \mathrm{~mm}$ selected against calanoids, but not to the extent shown in smaller-sized fish. No cladocerans were collected in any of the drop net samples in January, indicating they were a rare component of the plankton. However, they were con- sumed by $T$. maccoyii, which suggests a positive selection for this taxon. Insufficient numbers of larval $T$. maccoyii were caught in the November cruise to examine prey selection in this species further (see Table 6).

In both size classes of Thunnus alalunga, selectivity for copepod nauplii varied between samples in January 
and was not significant in November indicating little or no selection for this taxa (Table 4). In contrast, there was positive selection for corycaeids (mainly Farranula spp.) in both size classes. This result was supported from the pup net samples taken in November (Table 4). The very high selection values for corycaeids is mirrored by their dominance in the diet of $T$. alalunga (Table 1). Larvae of $T$. alalunga selected against calanoids in all the comparisons made, particularly in fish $\leq 5 \mathrm{~mm}$.

The small number of Katsuwonus pelamis limited analysis of prey selection. However, significant prey selection for appendicularians was obvious in all comparisons made (Table 4). As the proportion of fish larvae in the diet was much higher than that in the environment, it is likely that $K$. pelamis is also selecting for fish larvae. Very few crustacea were found in the stomachs of $K$. pelamis, indicating selection against these taxa

\section{Diurnal feeding pattern}

Thunnus maccoyii fed only in daylight (Fig. 7). Within these hours (08:00 to 19:30 h) there were signifi-

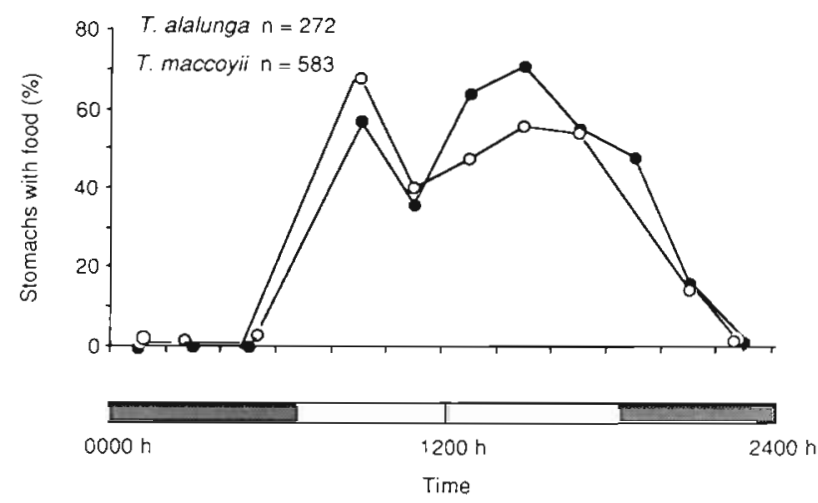

Fig. 7 Tunnus maccoyii $(\bullet$ ) and $T$. alalunga (c). Relátionship between time of day and proportion of larvae feeding cant differences in stomach fullness and numbers of prey eaten (Table 5). No significant difference was found in the state of digestion. Nonparametric multiple comparisons of stomach fullness and numbers of prey eaten between different times of day showed that feeding peaked after sunrise and in the midafternoon and dropped at mid-morning (Dunn test, $\mathrm{p}<0.001$ ) (Fig. 7).

Thunnus alalunga also fed only in the daylight hours (Fig. 7), although there was no significant difference in any of the feeding indices between different times of the day (Table 5) during January 1987. However, as the pattern of feeding was very similar to that in $T$. maccoyii (Fig. 7), the lack of significance may be the result of a smaller sample size. Evidence of increased feeding at dusk was found in November 1987 during the gut evacuation experiment. Feeding was also confined to daylight in Katsuwonus pelamis, but the lack of specimens and the low incidence of feeding limited further analysis

\section{Gut evacuation and feeding rate}

Very few Thunnus maccoyii were taken in the gut evacuation experiment in November $1987(n=25)$, and the stomachs of only 12 of these contained food (Table 6). However, sufficient numbers of $T$. alalunga containing food were taken to enable us to determine the rate of digestion in this species. Stomach fullness values rose to a maximum between 18:00 and 19:30 h, indicating peak feeding at this time. Regression of number of prey in individual stomachs against time after the time of peak feeding $(18: 30 \mathrm{~h})$ indicated that evacuation was completed by ca 22:00 h (Fig. 8) giving a gut evacuation time of between 3 and $4 \mathrm{~h}$, at a water temperature of $26^{\circ} \mathrm{C}$. Similar digestion times were shown by the decline in stomach fullness $(s)[\ln (s+1)=-0.168 \mathrm{t}+$ 1.42, $\mathrm{r}^{2}=0.37, \mathrm{df}=27, \mathrm{p}<0.001 \mathrm{]}$ and state of digestion (d) $\left[\ln (d+1)=-0.254 t+1.62, r^{2}=0.39, d f=27, p<\right.$ 0.001 ] over the same time $(\mathrm{t})$.

Table 5. Thunnus maccoyii, $\mathrm{T}$ alalunga. Results of Kruskal-Wallis test which tested the null hypothesis $\left(\mathrm{H}_{0}\right)$ that there was no significant difference in feeding between different times of the day. H: test statistic; df: degrees of freedom; $n$ : number of stomachs. Daytime was divided into five $2 \mathrm{~h}$ categories from 08:30 h

\begin{tabular}{|c|c|c|c|c|c|}
\hline Variable tested & $\mathrm{H}$ & df & $\mathrm{n}$ & Significance & Result \\
\hline \multicolumn{6}{|l|}{ I maccoyii } \\
\hline Stomach fullness & 46.8 & 4 & 409 & $p<0.001$ & Reject $\mathrm{H}_{0}$ \\
\hline Number of prey & 37.6 & 4 & 409 & $p<0.001$ & Reject $\mathrm{H}_{0}$ \\
\hline State of digestion & 8.4 & 4 & 409 & $0.1>p>0.5$ & Accept $\mathrm{H}_{0}$ \\
\hline \multicolumn{6}{|l|}{$T$. alalunga } \\
\hline Stomach fullness & 5.7 & 4 & 220 & $p>0.05$ & Accept $H_{0}$ \\
\hline Number of prey & 5.4 & 4 & 220 & $p>0.05$ & Accept $H_{i j}$ \\
\hline State of digestion & 4.3 & 4 & 121 & $p>0.05$ & Accept $\mathrm{H}_{0}$ \\
\hline
\end{tabular}




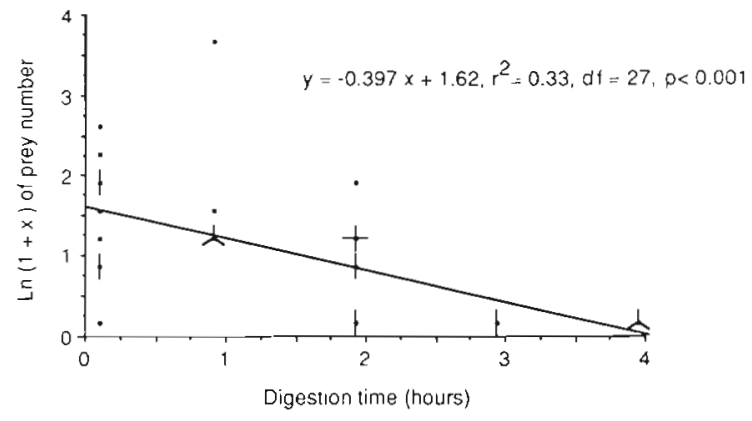

Fig. 8. Thunnus alalunga. Reduction in log-transformed prey numbers of larvae sampled from sunset $(18: 30 \mathrm{~h}$, equivalent to $0 \mathrm{~h}$ on $\mathrm{x}$-axis) to $23: 00 \mathrm{~h}$ during gut evacuation experiment. Spokewheel pattern on some points refers to number of overlapping points

\section{Daily ration}

The daily ration of Thunnus maccoyii was estimated, using the gut evacuation rate estimated for $T$. alalunga, at $10.1 \pm 2.7$ (95\% CL) prey larva ${ }^{-1} \mathrm{~d}^{-1}$, for all size classes combined. Using the conversions of prey size to dry weight for copepods given by Economou (1987) and our own unpublished data, the amount eaten was calculated to be ca $50( \pm 15) \mu g$ dry wt larva ${ }^{-1} \mathrm{~d}^{-1}$. We calculated the relationship between standard length and dry weight for T. maccoyii in our samples (Fig. 9), and for a larva of $4.5 \mathrm{~mm} \mathrm{SL}$ ( $150 \mu \mathrm{g}$ dry wt) daily food consumption is ca $30 \%$ of body weight. The daily ration of $T$. alalunga was estimated at $7.7 \pm 2.6(95 \%$ CL) prey larva ${ }^{-1} \mathrm{~d}^{-1}\left(39[ \pm 12] \mu \mathrm{g}\right.$ dry wt larva $\left.{ }^{-1} \mathrm{~d}^{-1}\right)$, or ca $25 \%$ of body weight.

\section{Relationship of feeding to biomass of zooplankton}

In Thunnus maccoyil there was a positive relationship between zooplankton settled volume (biomass) and both stomach fullness ( $r=0.72, p<0.001)$ and \% positive stomachs $(r=0.63, p<0.005)$ (Fig. 10). Similar

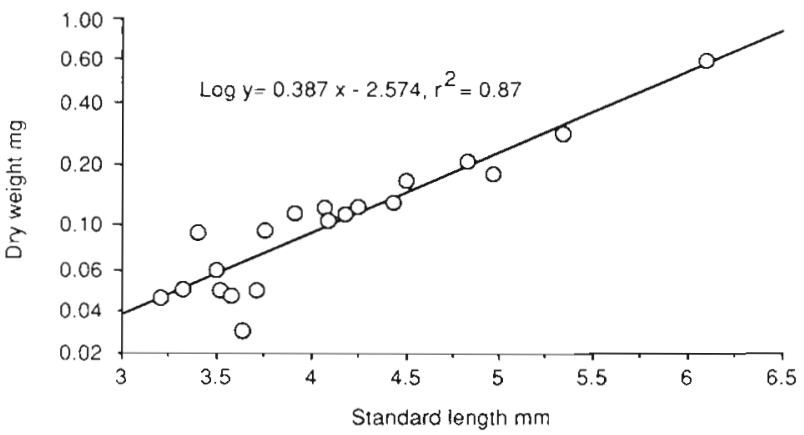

Fig. 9. Thunnus maccoyii. Relationship between standard length and dry body weight of larvae

relationships were found between displacement volume and the above feeding indices (stomach fullness $r$ $=0.60, \mathrm{p}<0.01 ; \%$ positive stomachs $\mathrm{r}=0.54, \mathrm{p} .<$ $0.05)$.

\section{DISCUSSION}

\section{Feeding incidence}

Less than half the larvae examined had food in their stomachs, and this proportion increased in larvae less than $5 \mathrm{~mm}$ SL. Such low feeding levels are common in seacaught larvae (Berner 1959, May 1974) and have previously been reported for oceanic larval scombrids (Nishikawa 1975). The high incidence of feeding found in larval Scomberomorus spp. by Jenkins et al. (1984) is an exception, but as these are inshore species, this may be because food is more plentiful. Although the levels found in the present study could have been an artefact of sampling - the larvae may regurgitate their food on capture (Last 1980) - the low feeding incidence was clearly related to food availability, as feeding incidence was closely correlated with food density.

Low feeding incidence was most noticeable in Katsuwonus pelamis, and was similar to that found by

Table 6. Summary of main prey taxa of Thunnus maccoyii (size range SL $=3.69$ to $7.37 \mathrm{~mm}$, mean $=4.63 \pm 0.84[\mathrm{SD}] \mathrm{mm}$ ) and $T$. alalunga $(\mathrm{SL}=3.59$ to $9.17 \mathrm{~mm}$, mean $=5.21 \pm 1.30[\mathrm{SD}] \mathrm{mm}$ ) identified from gut evacuation experiment in November $1987 . \mathrm{F}: \%$ frequency of occurrence; $N$ : \% number; Range: range of number of prey per larva

\begin{tabular}{|c|c|c|c|c|c|c|c|c|}
\hline \multirow[t]{2}{*}{ Prey Taxon } & \multicolumn{4}{|c|}{$T$ maccoyii $(n=25)$} & \multicolumn{4}{|c|}{$T$. alalunga $(\mathrm{n}=65)$} \\
\hline & $F$ & $\mathrm{~N}$ & F.N & Range & $F$ & $N$ & F.N & Range \\
\hline +ve stomachs $(\%)$ & \multicolumn{4}{|c|}{57.32} & \multicolumn{4}{|c|}{72.31} \\
\hline Calanoida & 20.00 & 38.46 & 769.20 & $0-1$ & 23.08 & 10.67 & 246.26 & $0-2$ \\
\hline Cyclopoida & 30.00 & 53.85 & 1615.5 & $0-2$ & 53.85 & 77.53 & 4174.99 & $0-29$ \\
\hline Nauplii & 4.00 & 7.69 & 30.76 & $0-1$ & 12.31 & 4.49 & 55.27 & $0-1$ \\
\hline Cladocera & - & - & - & - & 13.85 & 7.30 & 101.11 & $0-3$ \\
\hline No. of prey identified & \multicolumn{4}{|c|}{13} & \multicolumn{4}{|c|}{178} \\
\hline
\end{tabular}



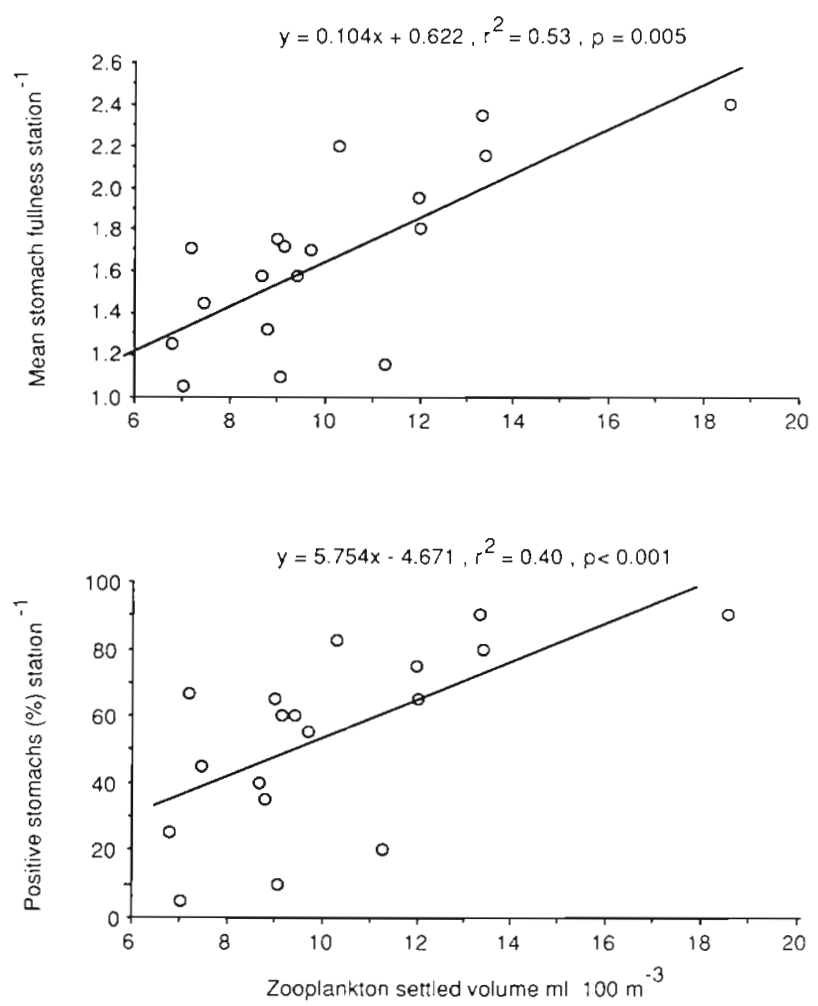

Fig. 10. Thunnus maccoyii. Relationship of zooplankton settled volume to mean larval stomach fullness and to \% positive stomachs $(\%$ positive stomachs calculated as the proportion of stomachs containing food at each station; each point represents at least 20 larvae)

Nishikawa (1975) in an earlier study of the same species. He suggested it may be related to the simple (straight) gut of the larvae, as food is more easily regurgitated by such larvae than by larvae with looped guts (Arthur 1976). However, rapid digestion of softbodied appendicularians, which are the major component of the diet of this species, may have been a contributing factor. Last (1980) found a similarly low feeding incidence in larval flounder Arnoglossuss sp., which also feeds on appendicularians.

\section{Diet overlap}

Although the diets of the 2 Thunnus species overlapped, the relative proportions of prey items differed. The clear progression in Thunnus maccoyii from smaller (nauplii) to larger prey taxa (calanoids) with increasing size is consistent with the diets of most marine larvae (Hunter 1981). However, in $T$. alalunga, as the larvae grow their diet is increasingly dominated by corycaeids, which resulted in less prey overlap between the 2 species. This is similar to the divergence in prey with size found by Jenkins (1987) in 2 co-occurring species of larval flounder Clearly the greatest difference in feeding (e.g. diet overlap, prey selectivity) was found between the 2 Thunnus species and Katsuwonus pelamis. Differences in diet may be related to mouth size, as relative mouth size increases from $T$. alalunga to $T$. maccoyii and finally to $K$. pelamis (Fig. 4). This is supported by the fact that prey size (width) is closely correlated with mouth width in all 3 species.

\section{Prey selection}

The pooling of larvae collected over a relatively large area in relation to the much smaller area over which a larva feeds limits the analysis of prey selection. However, as Govoni et al. (1986a) argued, it is important to get enough larvae containing prey to produce a reliable result. By comparing larval diets with discrete microzooplankton samples from different areas of the study area we hoped to avoid the effects of pooling data. The approach would appear to be valid as the selectivity values obtained were very similar at a number of stations. That we found very similar results on a later cruise (November 1987) using more discrete sampling methods adds further support. Uotani et al. (1981) compared prey selectivity of larval tunas taken from a wide geographic range (total area $=90000 \mathrm{~km}^{2}$ ) and found results very similar to the present study. For example, they found that Thunnus maccoyii and $T$. alalunga selected for Corycaeus spp. and that Katsuwonus pelamis selected for appendicularians. Similarly, they found that all 3 species selected against calanoids. They, like us, also found that $T$. alalunga, and in some areas $T$. maccoyii, selected against copepod nauplii. This contrasts to selectivity studies of other larvae (Lasker 1981), including scombrids (Peterson \& Ausubel 1984), where selection for copepod nauplii has neen noted

\section{Diurnal feeding}

Feeding was confined to daylight hours in all 3 species, which is characteristic of most (see Hunter 1981), but not all, larval fish examined to date (e.g. Arthur 1976, Sumida \& Moser 1980, Jenkins 1987). In the 2 Thunnus species, feeding peaked in the morning and again in the afternoon. Last (1978a, b, 1980) found similar patterns of feeding in a number of fish larvae in the North Sea, although he found a steady increase in stomach. fullness (after an initial burst at sunrise) throughout the day in these fish, with a late feeding peak near sunset. The present study found a decline in stomach fullness in the middle of the day. 
However, this decline may be related to faster rates of digestion in the tuna, because of warmer sea temperature (Laurence 1971), rather than to different feeding patterns.

\section{Digestion and daily ration}

Digestion in larval fishes generally takes between 1 and 4 h (Govoni et al. 1982, Fossum 1983, Jenkins 1987), although longer times have been reported (Theilacker \& Dorsey 1980). For example, Bay anchovy Anchoa mitchilli defecated within minutes after eating (Chitty 1981), whereas larvae of Atlantic menhaden Brevoortia patronus and spot Leiostomus xanthurus began defecating 1 to 2 h after eating (Govoni et al. $1986 \mathrm{~b}$ ). The age of larvae, prey type, prey size, and water temperature (see reviews in Govoni et al. 1986b, Theilacker \& Dorsey 1980) can affect the speed of digestion. In the present study we found that gut evacuation took 3 to $4 \mathrm{~h}$ in Thunnus alalunga, which may be the same in $T$. maccoyii, as their morphology and prey are similar. This time is about half that estimated by Hunter \& Kimbrell (1980) for the scombrid Scomber japonicus. However, this may be because $S$. japonicus larvae live in cooler waters $\left(19^{\circ} \mathrm{C}\right.$ in their study).

Peterson \& Ausubel (1984) calculated the daily ration of Scomber scombrus as between 17.7 (for a $3.75 \mathrm{~mm}$ SL larvae) and 87.6 (for a $5.75 \mathrm{~mm}$ SL larvae) $\mu \mathrm{g}$ dry $w \mathrm{t}$ larva ${ }^{-1} \mathrm{~d}^{-1}$, or between ca 25 and $50 \%$ of larval body weight $\mathrm{d}^{-1}$, which is similar to that found for Thunnus maccoyii in the present study. Hunter \& Kimbrell (1980) reported a higher consumption $(87 \%)$ for Scomber japonicus but this figure was from larvae reared in aquaria where food was plentiful.

\section{Niche separation}

During the daytime more Thunnus alalunga $168 \%$ of total sample) were found in the surface $2 \mathrm{~m}$ than in deeper waters; only $19 \%$ of $T$. maccoyii and no Katsuwonus pelamis were found at the surface during the day (Davis et al. 1990). These 3 species appear to be separated spatially in the water column during the daytime when they feed. Differences in their diets, such as in diet breadth and prey selection, also indicate separation in their feeding habits. Govoni et al. (1983) found spatial separation and partitioning of food resources in the larvae of 3 co-occurring fish species in the Gulf of Mexico and suggested that this 'may be a behavioural adaptation that mitigates periods of low food supply' (p. 197).

\section{Food limitation and predatory impact}

Recent studies have indicated that inter- and intraspecific competition in larval fish may be generally low, as larval fish are generally too few to affect the abundance of their prey (e.g. Cushing 1983, Jenkins 1987). Peterson \& Ausubel (1984) calculated that mackerel larvae Scomber scombrus were not sufficiently abundant to have an impact on the zooplankton. In the present study, however, we found evidence to suggest that larvae of Thunnus maccoyii can affect the abundance of their prey. The biomass of microzooplankton was an order of magnitude less than that found in other open-ocean studies (Hunter 1981). In contrast, larval fish densities were high in the study area (Davis \& Clementson in press). Davis (unpubl.) calculated the average density of $T$. maccoyii in the study area at 0.29 larvae $\mathrm{m}^{-3}$ (range 0 to 2.52 larvae $\mathrm{m}^{-3}$ ). Microzooplankton densities were variable (Table 3); however, using minimum and maximum densities of preferred prey (see Table 4), and estimates of daily ration, an assessment of the impact of larval $T$. maccoyii on prey stocks can be made. Each larval T. maccoyii can consume ca 10 microzooplankton prey $\mathrm{d}^{-1}$ which is, on average, 2.9 microzooplankton $\mathrm{m}^{-3} \mathrm{~d}^{-1}$, or using data from Tables 1 and 3, ca 3 to $5 \%$ of the cyclopoid population (or ca 1 to $15 \%$ of copepod nauplii). Bollens (1988) argued that population parameters (e.g. reproduction, mortality) of prey species, which are not included in our calculations, should be considered. Nevertheless, the removal rates reported here are similar to (or higher than) those reported for other 'predator' species -0.5 to $3.5 \%$ removal rates by predatory zooplankton have been shown to limit copepod prey populations (Ohman 1986). These larvae may, therefore, have an impact on prey densities. Cushing (1983) proposed that prey mortality increases as larval fish approach 'the age of metamorphosis', because of the increased hunting skills of the developing larvae, to an extent that it may generate densitydependent growth. We suggest that it is possible that such density-dependence can occur earlier in the larval stage in populations of T. maccoyii.

Acknowledgements. We thank the captain and crew of FRV 'Soela' for their cooperation and assistance at sea, and Dr G. P. Jenkins, Mr D. W. Rimmer, Ms J. L. May and Mr O. Augustine for help with collecting samples. In particular we thank Ms P. Bonham for sorting and weighing the microzooplankton samples, $\mathrm{Mr} \mathrm{O}$. Augustine for measuring larvae, $\mathrm{Mr}$ A. McKinnon (AIMS), Dr F. Koga (Sekai Reg. Fish. Lab.) and Ms P. McWilliam for helping identify copepods, and Dr G. P. Jenkins for many useful discussions. Ms S. E. Wayte gave valuable statistical advice. We thank Drs R. E. Johannes, F, R. Harden Jones and V Mawson, and Mr J. G. Gunn and 3 anonymous referees for their constructive comments on the manuscript. 


\section{LITERATURE CITED}

Angel, M. V (1977). Windows into a sea of confusion: sampling limitations to the measurement of ecological parameters in oceanic mid-water environments. In: Anderson, $N$. R., Zahuranec, B. J. (eds.) Oceanic sound scattering prediction. Plenum Press, New York, p. 217-248

Arthur, D. K. (1976). Food and feeding of larvae of three fishes occurring in the California Current: Sardinops sagax, Engraulis mordax and Trachurus symmetricus. Fish. Bull. U.S. 74: $517-530$

Berner, L. (1959). The food of the larvae of the northern anchovy Engraulis mordax. Inter.-Am. Trop. Tuna Comm. Bull. $4: 1-22$

Bollen, S. M. (1988). A model of the predatory impact of larval marine fish on the population dynamics of their prey. J. Plankton Res. 10: 887-906

Chitty, N. (1981). Behavioural observations of feeding larvae of bay anchovy, Anchoa mitchilli, and bigeye anchovy, Anchoa lamprotaenia. Rapp. P.-v. Réun. Cons. int. Explor. Mer. 178: 320-321

Cushing, D. H. (1983). Are fish larvae too dilute to affect the density of their prey? J. Plankton Res. 5: 847-854

Davis, T L. O., Clementson, L. A. (1989). Data report on the vertical and horizontal distribution of tuna larvae in the East Indian Ocean, January-February 1987, CSIRO Marine Lab. Rep. 206

Davis, T L. O., Jenkins, G. P., Young, J. W. (1990). Diel patterns of vertical distribution in larvae of southern bluefin Thunnus maccoyii, and other tuna in the East Indian Ocean. Mar. Ecol. Prog. Ser. 59: 63-74

Economou, A. N. (1987). Ecology of survival in some gadoid larvae of the northern North Sea. Environ. Biol. Fish. 19:241-260

Elliot, J. M., Persson, L. (1978). The estimates of daily food consumption for fish. J. Anim. Ecol. 47.977-991

Fossum, P. (1983). Digestion rate of food particles in the gut of larval herring. FiskDir. Skr. (Ser Havunders.) 17: 347-357

Frank, K. T (1988). Independent distributions of fish larvae and their prey: natural paradox or sampling artefact? Can. J. Fish. Aquat. Sci. 45: 48-59

Govoni, J. J., Boehlert, G. H., Watanabe, T. (1986b). The physiology of digestion in fish larvae. Environ. Biol. Fish. 16: 59-77

Govoni, J. J., Hoss, D. E., Chester, A. J. (1983). Comparative feeding of three species of larval fishes in the northern Gulf of Mexico: Brevoortia patronus, Leiostomus xanthurus, and Micropogonias undulatus. Mar. Ecol. Prog. Ser 13: 189-199

Govoni, J. J., Ortner, P. B., Al-Yamani, F., Hill, L. C. (1986a). Selective feeding of spot, Leiostomus xanthurus, and Atlantic croaker, Micropogonias undulatus, larvae in the northern Gulf of Mexico. Mar. Ecol. Prog. Ser 28: 175-183

Govoni, J. J., Peters, D. S., Merriner, J. V (1982). Carbon assimilation during the larval development of the marine teleost Leiostomus xanthurus Lacepede. J. exp. mar. Biol. Ecol. 64 : 287-299

Heron, A. C. (1982). A vertical free fall plankton net with no mouth obstructions. Limnol. Oceanogr. 27: 380-383

Hespenheide, H. A. (1975). Prey characteristics and predator niche width. In: Cody, M. L., Diamond, J. M. (eds.) Ecology and evolution of communities. Belknap Press, Cambridge, Mass., p. $158-180$

Hjort, J. (1914). Fluctuations in the great fisheries of northern Europe viewed in the light of biological research. Rapp. P.v. Réun. Cons. perm int. Explor. Mer. 20: 1-228

Hunter, J. R. (1981). Feeding ecology and predation of marine fish larvae. In: Lasker, R. (ed.) Marine fish larvae: morphology, ecology, and relation to fisheries. Washington Sea Grant Program, Seattle, p. 34-77
Hunter, J. R., Kimbrell, C. A. (1980). Early life history of Pacific mackerel, Scomber japonicus. Fish. Bull. U.S. 78: 89-101

Jenkins, G. P. (1987). Comparative diets, prey selection, and predatory impact of co-occurring larvae of two flounder species. J. exp. mar Biol. Ecol. 110: 147-170

Jenkins, G. P., Milward, N. E., Hartwick, R. F. (1984). Food of larvae of Spanish mackerels, genus Scomberomorus (Teleostei: Scombridae), in shelf waters of the Great Barrier Reef. Aust. J. mar Freshwat. Res. 35: 477-482

Lasker, R. (1975). Field criteria for survival of anchovy larvae: the relation between inshore chlorophyll maximum layers and successful first feeding. Fish. Bull. U.S. 73: 453-462

Lasker, R. (1981). Marine fish larvae: morphology, ecology, and relation to fisheries. Washington Sea Grant Program, Seattle

Last, J. M. (1978a). The food of four species of pleuronectiform larvae in the eastern English Channel and southern North Sea. Mar. Biol. 45: 359-368

Last, J. M. (1978b). The food of three species of gadoid larvae in the eastern English Channel and southern North Sea. Mar. Biol. 48: 377-386

Last, J. M. (1980). The food of twenty species of fish larvae in the west-central North Sea. Fish. Res. Tech. Rep. No. 60, $44 \mathrm{pp}$

Laurence, G. C. (1971). Digestion rates of larval largemouth bass. N. Y. Fish. Game J. 18: 52-56

Lechowicz, M. J. (1982). The sampling characteristics of electivity indices. Oecologia (Berl.) 52: 22-30

Levins, R. (1968). Evolution in changing environments. Princeton University Press, Princeton

May, R. C. (1974). Larval mortality in marine fishes and the critical period concept. In: Blaxter, J. H. S. (ed.) The early history of fish. Springer-Verlag, New York, p. 1-19

Merrett, N. R., Roe, H. S. J. (1974). Patterns and selectivity in the feeding of certain mesopelagic fishes. Mar. Biol. 28: $115-126$

Nishikawa, Y (1975). Feeding of larval and juvenile skipjack in relation to the development of their stomachs. Bull. Far Seas Fish. Res. Lab. (Shimizu) 12: 221-236

Nishikawa, Y (1985). Identification for larvae of three species of genus Thunnus by melanophore patterns. Bull. Far Seas Fish. Res. Lab. (Shimizu) 22: 11.9-130

Nishikawa, Y., Rimmer, D. W. (1987). Identification of larval tunas, billfishes and other scombroid fishes (suborder Scombroidei): an illustrated quide CSIRO Mar. Lab. Rep. $186,20 \mathrm{pp}$

Ohman, M. D. (1986). Predator-limited population growth of the copepod Pseudocalanus sp. J. Plankton Res. 8: 673-713

Omori, M., Ikeda, T (1984). Methods in marine zooplankton ecology. Wiley-Interscience, New York

Pearre, S. (1982). Estimating prey preference by predators: uses of varrous indices, and a proposal of another based un $\mathrm{X}^{2}$ Can. J. Fish. Aquat. Sci. 39: 914-923

Pearre, S. (1986). Ratio-based trophic niche breadths of fish, the Sheldon spectrum, and the size efficiency hypothesis. Mar. Ecol. Prog. Ser 27: 299-314

Peterson, W. T., Ausubel, S. J. (1984). Diets and selective feeding by larvae of Atlantic mackerel Scomber scombrus on zooplankton. Mar. Ecol. Prog. Ser 17:65-75

Richards, W J., Potthoff, T., Kim, J. (in press). Problems identifying tuna larvae species (Pisces: Scombridae: Thunnus) from the Gulf of Mexico. Fish. Bull. U.S.

Rochford, D. J. (1962). Hydrology of the Indian Ocean. Part II The surface waters of the southeast Indian Ocean and the Arafura Sea in the spring and summer. Aust. J. mar. Freshwat. Res. 13: 226-251

Schmitt. P. D. (1986). Feeding by larvae of Hypoatherina 
tropicalis (Pisces: Atherinidae) and its relation to prey availability in One Tree Lagoon, Great Barrier Reef, Australia. Environ. Biol. Fish. 16: 79-94

Schoener, T W (1970). Non-synchronous spatial overlap of lizards in patchy habitats. Ecology 51.408-418

Sumida, B. Y., Moser, H. G. (1980). Food and feeding of Pacific hake larvae, Merluccius productus, off southern California and northern Baja California. Rep. Calif. coop. ocean. Fish. Invest. (Cal CO FI) 21: 161-165

Theilacker, G., Dorsey, K. (1980). Larval fish diversity, a sum-

This article was submitted to the editor mary of laboratory and field research. UNESCO, Int. Oceanogr. Comm. Workshop Rep. 28: 105-142

Uotani, I., Matsuzaki, K., Makino, Y., Noda, K., Inamura, O., Horikawa, M. (1981). Food habits of larvae of tunas and their related species in the area northeast of Australia. Bull. Jap. Soc. scient. Fish. 47: 1165-1172

Wallace, R. K. (1981). An assessment of diet-overlap indices. Trans. Am. Fish. Soc. 110: 72-76

Zar, J. H. (1984). Biostatistical analysis, 2nd edn. Prentice Hall, Englewrood Cliffs, N. J.

Manuscript first received: August 22, 1989

Revised version accepted: November 23, 1989 